\title{
IMPLEMENTASI FUZZY LOGIC PENENTUAN KELAYAKAN KARYAWAN MENDAPAT REWARD DITOKO ROTI MENGUNAKAN METODE TSUKAMOTO
}

\author{
Syahnandar ${ }^{1}$, Rahmat Hidayatullah $^{2}$, Nur Rubiati ${ }^{3}$, Rahmad Kurniawan $^{4}$ \\ ${ }_{1,2,3,4}$ Kampus Sekolah Tinggi Manajemen Informatika dan Komputer (STMIK) Dumai \\ JL. Utama Karya Bukit Batrem Kec. Dumai Timur Kode pos 28811 \\ e-mail : syahnandar14@gmail.com
}

\begin{abstract}
ABSTRAK
Karyawan merupakan elemen penting didalam sebuah perusahaan yang akan menentukan kemajuan disuatu perusahaan tersebut, oleh kerna itu untuk meniggkatkan prestasi kinerja karyawan agar lebih efektif dalam melakukan tugas maka dibuatlah sebuah prongram penilaian dalam bentuk reward, pemberian reward ini hanyalah bertujuan meniggkatkan prastasi dalam perkejaaan agar lebih bersikap profesional, dikarnakan belum adanya sebuah aplikasi sebagai alat bantu pemilih karyawan yang berhak mendapat reward secara tepat. maka digunakanlah Sistem Pendukung Keputusan, yaitu metode fuzzy logic Tsukamoto dengan menerapkan variabel-variabel sebagai data pendukung yang meliputi Kinerja Kedisiplinan dan Kemampuan yang menjadi kriteria dalam penilaian. Tujuan penelitian ini adalah untuk mempermudahkan usaha roti canai dalam penentuan kelayakan karyawan yang akan mendapat reward. Pemberian reward ini disesuai dengan keadaan serta kualitas yang dimiliki sehingga reward dapat diberikan kepada karyawan secara objektif.
\end{abstract}

Kata kunci : Fuzzy Logic, Metode Tsukamoto, Reward Karyawan, PHP

\section{PENDAHULUAN}

Karyawan merupakan elemen penting dalam suatu perusahaan yang akan menentukan kemajuan sebuah usaha, dalam rangka memberikan motivasi kepada karyawan, sebuah usaha roti canai mengadakan program penentuan kelayakan karyawan prestasi. Kegiatan ini dilakukan untuk memberikan motivasi kepada karyawan yang memiliki berprestasi, sebagai tanda ucapan terima kasih Pimpinan terhadap kinerja karyawan tersebut.

Permasalahan yang sering ditemukan disetiap akhir bulan pada tempat usaha roti canai ialah Penentuan kelayakan karyawan yang akan mendapat reward, dikerenakan belum adanya sebiah sistem sebagai alat bantu dalam pengambilan keputusan secara tepat

Untuk membantu usaha roti canai dalam pengambil keputusan karyawan yang berhak mendapatkan reward, maka digunakanlah Sistem Pendukung Keputusan, yaitu metode fuzzy logic Tsukamoto.

Tujuan penelitian ini adalah untuk mempermudahkan usaha roti canai dalam penentuan kelayakan karyawan yang akan mendapat reward.

\section{a. Kecerdasan Buatan}

Kecerdasan Buatan berasal dari (bahasa Inggris: Artificial Intelligence atau AI) didefinisikan sebagai kecerdasan yang ditunjukkan oleh suatu entitas ilmiah. Sistem seperti ini umumnya dianggap komputer. Kecerdasan diciptakan dan dimasukkan kedalam suatu mesin (komputer) agar dapat melakukan pekerjaan seperti yang dapat dilakukan manusia. Beberapa macam bidang yang menggunakan kecerdasan buatan antara lain sistem pakar, permainan komputer (games), logika fuzzy, jaringan syaraf tiruan dan robotika.(Wijaya, 2013)

\section{b. Logika Fuzzy}

logika fuzzy adalah suatu cara yang tepat untuk memetakan suatu ruang input ke dalam suatu ruang output. Teori himpunan fuzzy merupakan kerangka matematis yang digunakan untuk mempresentasikan ketidak pasti.(elisawati, 2017)

Logika fuzzy merupakan logika klasik dinyatakan bahwa segala sesuatu bersifat biner, yang artinya adalah hanya mempunyai dua kemungkinan, "Ya atau Tidak", "Benar atau 


\section{INFORM T I K A}

Jurnal Informatika, Manajemen dan Komputer, Vol. 10 No. 2, Desember 2017

eISSN : 2580-3042

pISSN : 1979-0694

Salah", "Baik atau Buruk", dan lain lain. Oleh karena itu, semua ini dapat mempunyai nilai keanggotaan 0 atau 1. Akan tetapi rada di antara 0 dan 1. Artinya, bisa saja suatu keadaan mempunyai dua nilai "Ya dan Tidak", "Benar dan Salah", "Baik dan Buruk"secara bersamaan, namun besar nilainya tergantung pada bobot keanggotaanyang dimilikinya.(Hasanh \& Widiastuti, 2014)

\section{c. Metode Sistem Inferensi Fuzzy}

Sistem inferensi fuzzy akan berfungsi sebagai pengendali proses tertentu dengan menggunakan aturan-aturan inferensi berdasarkan logika fuzzy.(Novita, 2019)

Sistem inferensi memiliki 4 unit yaitu

1. Unit fuzzifikasi (fuzzification unit)

2. Unit penalaran logika fuzzy (fuzzy logic reasoning unit)

3. Unit basis pengetahuan (knowledge base unit) yang terdiri dari :

4. 4.Unit defuzzifikasi / unit penegasan (defuzzification unit)

\section{d. Metode Tsukamoto}

Pada metode Tsukamoto, setiap konsekuen pada aturan yang berbentuk IF-THEN harus direpresentasikan dengan suatu himpunan fuzzy dengan fungsi keanggotaan yang monoton. Sebagai hasilnya, output hasil inferensi dari tiaptiap aturan diberikan dengan tegas.(Fristanto, 2013)

Setiap konsekuen pada aturan yang berbentuk If-Then harus direpresentasikan dengan suatu himpunan fuzzy dengan fungsi keanggotaan yang monoton. Sebagai hasilnya, output hasil inferensi dari tiap-

tiap aturan diberikan secara tegas (crisp) berdasarkan predikat. Hasil akhirnya diperoleh dengan menggunakan rata-rata terbobot.(Ekajaya, Hidayat, \& Ananta, 2018)

Fungsi Keanggotaan adalah suatu kurva yang menunjukkan pemetaan titik-titik input data kedalam nilai keanggotaannya (sering juga disebut dengan derajat keanggotaan) yang memiliki interval antara 0 sampai 1 . Salah satu cara yang dapat digunakan untuk mendapatkan nilai keanggotaan adalah dengan melalui pendekatan fungsi. Ada beberapa fungsi yang digunakan.(Hasanh \& Widiastuti, 2014)

Seperti nilai keanggotaan dibawah ini

1. Representasi Linear

Pada representasi linear, pemetaan input ke derajat keanggotannya digambarkan sebagai suatu garis lurus. Bentuk ini paling sederhana dan menjadi pilihan yang baik untuk mendekati suatu konsep yang kurang jelas.(Taufiq, 2016)

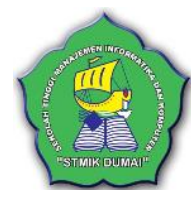

Ada 2 keadaan himpunan fuzzy yang linear. Pertama, kenaikan himpunan dimulai pada nilai domain yang memiliki derajat keanggotaan nol [0] bergerak ke kanan menuju ke nilai domain yang memiliki derajat keanggotaan lebih tinggi.(Murdianingsih \& Utomo, 2016)

Seperti grafik (fis) dibawah ini.

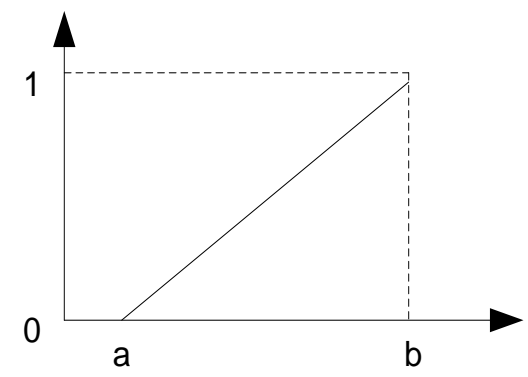

Gambar 1. Representasi Linear Naik. Sumber.(Iswandy, 2015)

$$
\mu[x]= \begin{cases}0 ; & x \leq a \\ (x-a) /(b-a) ; & a \leq x \leq b \\ 1 ; & x \geq b\end{cases}
$$

Kedua, merupakan kebalikan yang pertama. Garis lurus dimulai dari nilai domain dengan derajat keanggotaan tertinggi pada sisi kiri, kemudian bergerak menurun ke nilai domain yang memiliki derajat keanggotaan lebih rendah.

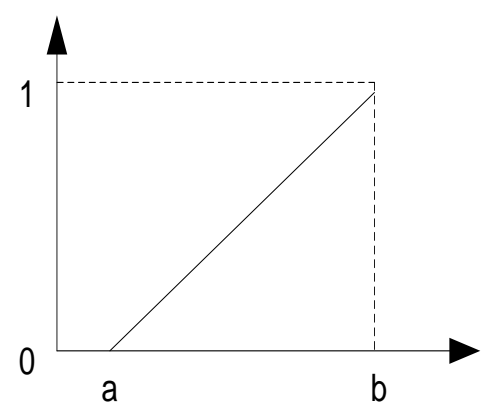

Gambar 2. Representasi Linear Turun. Sumber.(Iswandy, 2015)

$$
\mu[x]= \begin{cases}(b-x) /(b-a) ; & a \leq x \leq b \\ 0 ; & x \geq b\end{cases}
$$

\section{Representasi Kurva Segitiga}

Kurva Segitiga pada dasarnya merupakan gabungan antara 2 garis (linear) 
I N F O R M A T I K A

Jurnal Informatika, Manajemen dan Komputer, Vol. 10 No. 2, Desember 2017

eISSN : 2580-3042

pISSN : 1979-0694

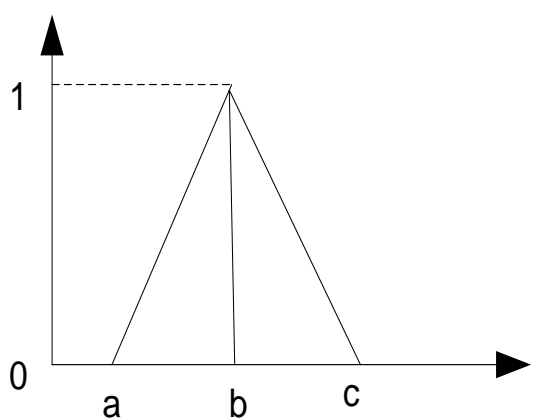

Gambar 3. KurvaSegitiga.

Sumber.(Iswandy, 2015)

$$
\mu[x]= \begin{cases}0 ; \\ (\mathrm{x}-\mathrm{a}) /(\mathrm{b}-\mathrm{a}) ; & \mathrm{a} \leq \mathrm{x} \leq \mathrm{b} \\ (\mathrm{b}-\mathrm{x}) /(\mathrm{c}-\mathrm{b}) ; & \mathrm{b} \leq \mathrm{x} \leq \mathrm{c}\end{cases}
$$

3. Representasi Kurva Trapesium

Kurva Segitiga pada dasarnya hanya saja ada beberapa titik yang memiliki nilai keanggotaan (1).

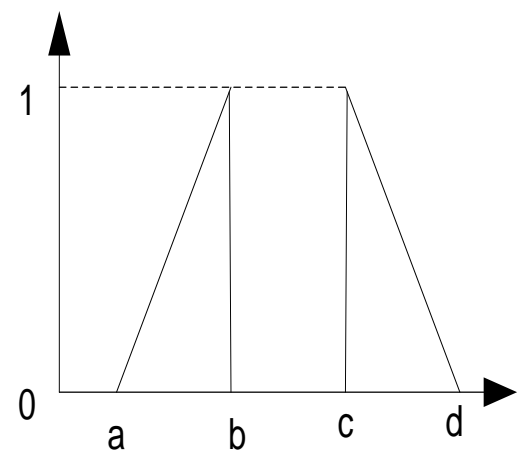

Gambar 4. Kurva Trapesium.

Sumber.(Iswandy, 2015)

$$
\mu[x]= \begin{cases}0 ; & x \leq a \text { atau } \mathrm{x} \geq \mathrm{d} \\ (\mathrm{x}-\mathrm{a}) /(\mathrm{b}-\mathrm{a}) ; & \mathrm{a} \leq \mathrm{x} \leq \mathrm{b} \\ 1 ; & \mathrm{b} \leq \mathrm{x} \leq \mathrm{c} \\ (\mathrm{d}-\mathrm{x}) /(\mathrm{d}-\mathrm{c}) ; & x \geq d\end{cases}
$$

\section{Representasi Kurva Bentuk Bahu}

Daerah yang terletak di tengah-tengah suatu variabel yang direpresentasikan dalam bentuk segitiga, pada sisi kanan dan kirinya akan naik dan turun (misalkan: DINGIN bergerak ke SEJUK bergerak ke HANGAT dan bergerak ke PANAS). menunjukkan variabel TEMPERATUR dengan daerah bahunya.

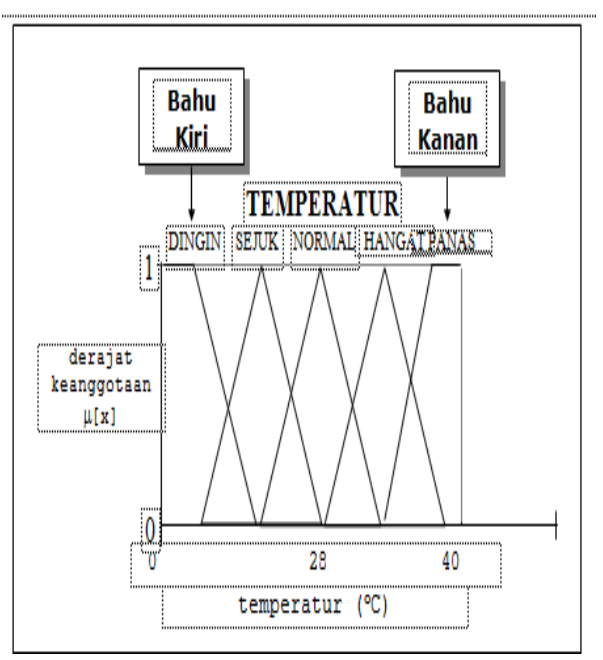

Gambar 5. Daerah 'bahu' TEMPERATUR. Sumber.(Iswandy, 2015)

Seperti halnya himpunan konvensional, ada beberapa operasi yang didefinisikan secara khusus untuk mengkombinasi dan memodifikasi himpunan fuzzy. Nilai keanggotaan sebagai hasil dari operasi dengan nama fire strength atau $\alpha-$ predikat.(Ekajaya et al., 2018)

Ada tiga penerapan yang digunakan dalam penyelesaian metode fuzzy logic yaitu:

1. Operator AND

Operator ini berhubungan dengan operasi interseksi pada himpunan. $\alpha$-predikat sebagai hasil operasi dengan operator AND diperoleh dengan mengambil nilai keanggotaan terkecil antar elemen pada himpunan-himpunan yang bersangkutan.(Ekajaya et al., 2018)

\section{Operator OR}

Operator ini berhubungan dengan operasi union pada himpunan. $\alpha$-predikat sebagai hasil operasi dengan operator OR diperoleh dengan himpunan-himpunan yang bersangkutan.(Nurul, 2016)

\section{Operator NOT}

Operator ini berhubungan dengan operasi komplemen pada himpunan. $\alpha$-predikat sebagai hasil operasi dengan operator NOT.(Dharmawati \& Aprilianto, 2014)

\section{METODOLOGI PENELITIAN}

Jenis PenelitianPenelitian ini merupakan penelitian eksperimen yaitu merancang sistem prediksi jumlah produksi roti berdasarkan data permintaan dan persediaanmenggunakan logika fuzzy diharapkan dapat membantu menentukan jumlah produksi roti 
I N F O R M A I I A

Jurnal Informatika, Manajemen dan Komputer, Vol. 10 No. 2, Desember 2017

eISSN : 2580-3042

pISSN : 1979-0694

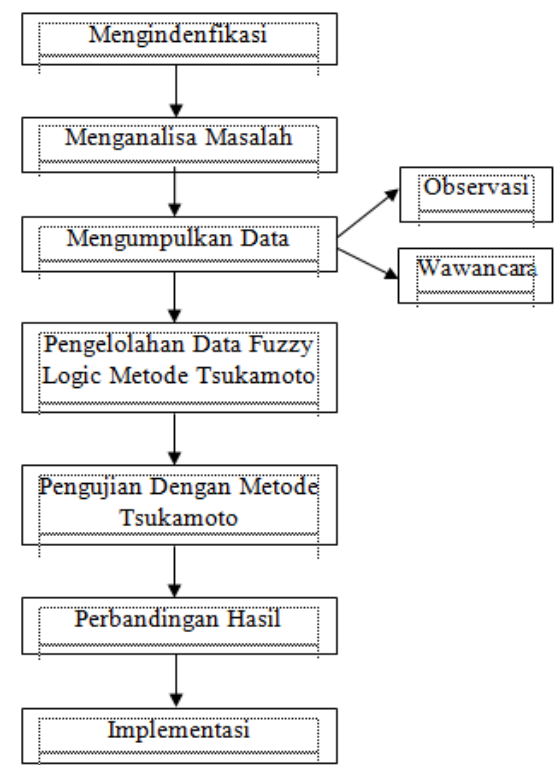

Gambar 6. Kerangka Pemikiran

Berikut ini adalah penjelasan kerangka penelitianmenggunakan metode fuzzy logic Tsukamoto yaitu:

1. Mengidentifikasi Masalah

Pada tahap ini dilakukan pengindentifikasikan terhadap masalah yang akan diteliti. Adapun permasalahan utama yang dihadapi ialah mengimplementasikan metode fuzzy logic Tsukamoto pada penentuan kelayakan karyawan untuk mendapatkan reward.

2. Menganalisa Masalah

Permasalahan yang ditemukan dalam identifikasi masalah ini ialah masih sulitnya pempinan dalam penentuan karyawan yang akan mendapat reward.

3. Mengumpulkan Data

Metode pengumpulan data dilakukan dengan cara melakukan pengamatan langsung pada perusahaan roti canai, di jalan Sudarso Dumai Timur. Selain melakukan secara langsung pengamatan juga dilakukan wawancara pada pihak yang berkaitan dengan kasus yang akan diselesaikan.

4. Pengolahan Data dengan metode fuzzy logic Tsukamoto

Setelah data terkumpul, selanjutnya dilakukan analisa terhadap data. Analisa data dilakukan dengan mengunakan metode fuzzy logic Tsukamoto dalam mendapatkan nilai yang terbobot.

a. Teknik Penerapan Fuzzy Tsukamoto dalam kelayakan terhadapan karyawan yang akan mendapat reward..

b. Inferensi (rule). Untuk mencarik nilai (minimun) yang digunakan untuk mencari nilai $\mathrm{z}$.

c. Menentukan Output Crisp (Deffuzzyfikasi) adalah hasil dari penjumlahan seluruh penilaian berdasarkan tahan metode fuzzy logic Tsukamoto

5. Pengujian metode fuzzy logic Tsukamoto

Proses dimana hasil yang diselesaikan dengan metode tsukamoto ialah untuk mendapatkan hasil yang diinginkan sesuai dengan kriteria-kriteria yang telah ditentukan, sehingga menghasilkan sebuah keluaran output sesuai yang diharapkan.

6. Perbandingan hasil.

Setelah penyelesaian secara dibandingkan dengan hasil pengujian sistem untuk menghasilkan sebuah output, hal ini akan disesuaikan dengan pencarian manual.

7. Implementasi

Proses penyelesaian dalam Tsukamoto kemudian mengimplementasikan sebuah sistem mulai dari penginputan data sampai proses penyelesaikan, sehingga mendapatkan hasil yang diinginkan.

\section{HASIL DAN PEMBAHASAN}

a. Analisa Penyelesaian Metode.

Input yang digunakan dalam penelitan ini adalah kriteria kelayakan yang memiliki nilai yang mendukung, nilai tersebut telah ditentukan berdasarkan kriteria yang ada, seperti kriteria kinerja, kedesiplinan dan kemampuan seperti tabel penilaian dibawah ini.

\section{Kinerja}

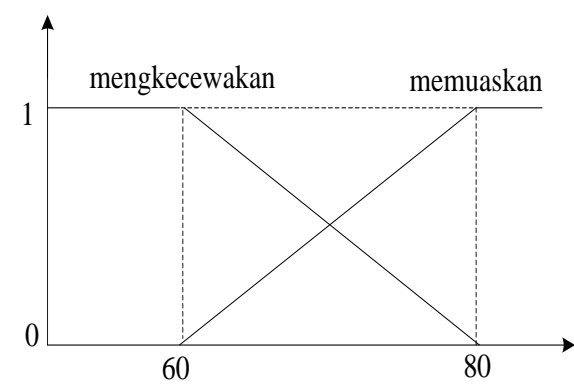

Gambar 7. Representasi kinerja 
IN F O RM A I K A

Jurnal Informatika, Manajemen dan Komputer, Vol. 10 No. 2, Desember 2017

eISSN : 2580-3042

pISSN : 1979-0694

2. Kedesiplinan

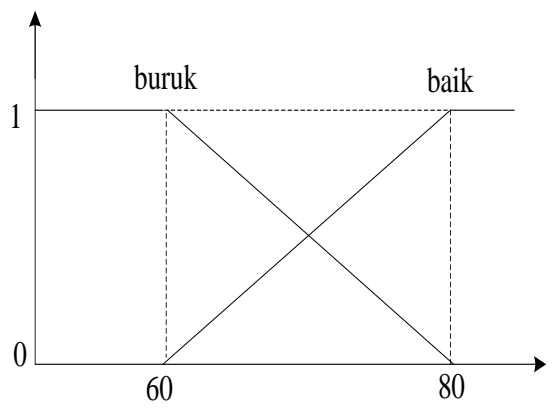

Gambar 8. Representasi Kedesiplinan

3. Kemampuan

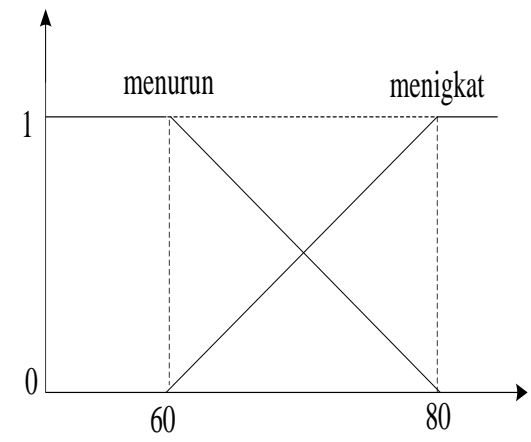

Gambar 9. Representasi Kemampuan

Didalam menentukan reward ada 8 aturan yang dapat bentukan yaitu:

[R1] IF Kinerja mengkecewakan AND Kedesiplinan buruk AND Kemampuan menurun THEN bonus tidak dapat.

[R2] IF Kinerja mengkecewakan AND Kedesiplinan buruk AND Kemampuan meningkat THEN bonus tidak dapat.

[R3] IF Kinerja mengkecewakan AND Kedesiplinan baik AND Kemampuan menurun THEN bonus tidak dapat.

[R4] IF Kinerja mengkecewakan AND Kedesiplinan baik AND Kemampuan meningkat THEN bonus dipertimbangkan.

[R5] IF Kinerja memuaskan AND Kedesiplinan buruk AND Kemampuan menurun THEN bonus tidak dapat.

[R6] IF Kinerja memuaskan AND Kedesiplinan baik AND Kemampuan menurun THEN bonus dipertimbangkan.

[R7] IF Kinerja memuaskan AND Kedesiplinan buruk AND Kemampuan meningkat THEN bonus dipertimbangkan.

[R8] IF Kinerja memuaskan AND Kedesiplinan baik AND Kemampuan meningkat THEN bonus dapat

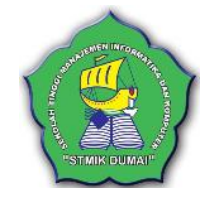

b. Output

Penentuan reward ini ditentukan setiap akhir bulan, dengan bertujuan untuk meningkat kualitas kinerja karyawan, maksud reward disini ialah berupa uang yang akan diberikan pada tiaptiap karyawan setelah melakukan penilaian berdasar kualitas yang dimiliki, variabel reward yang akan digunakan dalam penilaian ini terdiri dari 3 himpunan fuzzy yaitu" TIDAK DAPAT" , DIPERTIMBANGKAN" dan "DAPAT seperti tabel dibawah ini:

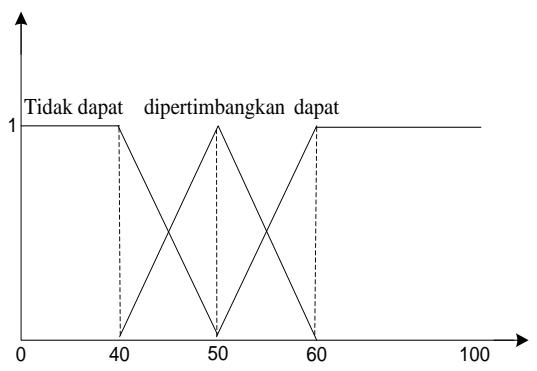

Gambar 10. Representasi Output

Untuk variabel reward dikategorikan kedalam himpunan fuzzy tidak dapat, dipertimbangkan, dan dapat. Untuk himpunan Fuzzy tidak dapat dan dapat menggunakan pendekatan fungsi keanggotaan.

$$
\text { Tidak dapat }(x)=\left\{\begin{array}{lc}
0 & X \leq 40 \\
\frac{50-X}{10} & 40 \leq X \leq 50 \\
1 & X \geq 50
\end{array}\right.
$$

Reward dipertimbangkan mengunakan nilai keanggotaan seperti terlihat dibawah ini:

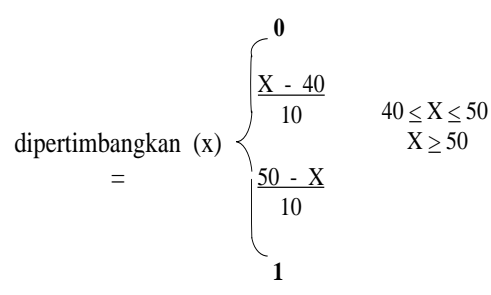

Reward dapat mengunakan nilai keanggotaan seperti terlihat dibawah ini: 
I N F O R M A T I K A

Jurnal Informatika, Manajemen dan Komputer, Vol. 10 No. 2, Desember 2017

eISSN : 2580-3042

pISSN : 1979-0694

$$
\text { dapat }(x)=\left\{\begin{array}{lc}
0 & x \leq 50 \\
\frac{x-60}{10} & \frac{50<X}{x} \leq 60 \\
1 & x \geq 60
\end{array}\right.
$$

Penelitian ini mengunakan beberapa data karyawan ditoko pembuatan roti, data yang diperoleh disesuaikan dengan penilaian dan kualitas dimiliki setiap karyawan seperti gambar dibawah ini:

Tabel 1. Representasi Nilai

\begin{tabular}{|c|c|c|c|}
\hline $\begin{array}{c}\text { Kriteria } \\
\text { I } \\
\text { Alternat } \\
\text { if }\end{array}$ & $\begin{array}{c}\text { Kine } \\
\text { rja }\end{array}$ & $\begin{array}{c}\text { Kedesipli } \\
\text { nan }\end{array}$ & $\begin{array}{c}\text { Kema } \\
\text { mpua } \\
\text { n }\end{array}$ \\
\hline Susi & 79 & 79 & 75 \\
\hline Lia & 79 & 78 & 75 \\
\hline Ansor & 78 & 79 & 78 \\
\hline
\end{tabular}

1. Himpunan fuzzy kinerja susi

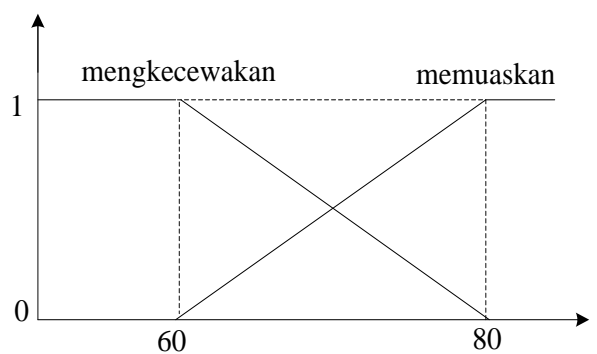

Rumus memuaskan $=(\mathrm{x}-\mathrm{a}) /(\mathrm{b}-\mathrm{a})$

Susi $(\mathrm{x})=79$

$$
=\operatorname{Dik}(\mathrm{a}=60)(\mathrm{b}=80)
$$

Penyelesaian:

$$
\begin{aligned}
\operatorname{Memuaskan}(\mathrm{x}) & =\frac{\mathrm{x}-60}{80-60} \\
\operatorname{Memuaskan}(79) & =\frac{79-60}{80-60} \\
& =\frac{79-60}{20} \\
& =\frac{19}{20}=0,95
\end{aligned}
$$

$$
\begin{aligned}
\text { mengkecewakan } & =(\mathrm{b}-\mathrm{x}) /(\mathrm{b}-\mathrm{a}) \\
& =\operatorname{Dik}(\mathrm{a}=60)(\mathrm{b}=80) \\
\text { Susi }(\mathrm{x}) & =79
\end{aligned}
$$

Penyelesaian:

$$
\begin{aligned}
\operatorname{mgkecewa}(\mathrm{x}) & =\frac{80-\mathrm{x}}{80-60} \\
\operatorname{mgkecewa}(79) & =\frac{80-79}{80-60} \\
& =\frac{80-79}{20} \\
& =\frac{1}{20}=0,05
\end{aligned}
$$

2. Himpunan fuzzy kedesiplinan susi

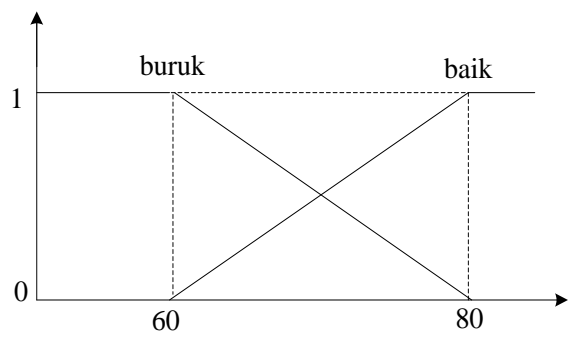

$$
\begin{aligned}
\text { Rumus baik } & =(\mathrm{x}-\mathrm{a}) /(\mathrm{b}-\mathrm{a}) \\
& =\operatorname{Dik}(\mathrm{a}=60)(\mathrm{b}=80) \\
\text { Susi }(\mathrm{x}) & =79
\end{aligned}
$$

Penyelesaian:

$$
\begin{aligned}
\operatorname{baik}(\mathrm{x}) & =\frac{\mathrm{x}-60}{80-60} \\
\operatorname{baik}(79) & =\frac{79-60}{80-60} \\
& =\frac{79-60}{20} \\
& =\frac{19}{20}=0,95
\end{aligned}
$$

$$
\begin{aligned}
\text { rumus buruk } & =(\mathrm{b}-\mathrm{x}) /(\mathrm{b}-\mathrm{a}) \\
& =\operatorname{Dik}(\mathrm{a}=60)(\mathrm{b}=80) \\
\text { Susi }(\mathrm{x}) & =79
\end{aligned}
$$

Penyelesaian:

$$
\begin{aligned}
\operatorname{buruk}(\mathrm{x}) & =\frac{80-x}{80-60} \\
\operatorname{buruk}(79) & =\frac{80-79}{80-60} \\
& =\frac{80-79}{20} \\
& =\frac{1}{20}=0,05
\end{aligned}
$$

3. Himpunan fuzzy kemampuan susi 
I N F O R M A T I K A

Jurnal Informatika, Manajemen dan Komputer, Vol. 10 No. 2, Desember 2017

eISSN : 2580-3042

pISSN : 1979-0694

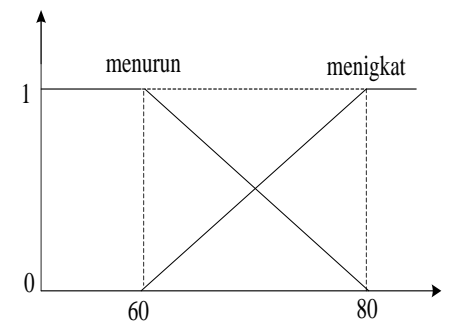

Rumus menigkat $=(x-a) /(b-a)$

Susi $(\mathrm{x})=75$

$$
=\operatorname{Dik}(\mathrm{a}=60)(\mathrm{b}=80)
$$

Penyelesaian:

$$
\begin{aligned}
\operatorname{menigkat}(x) & =\frac{x-60}{80-60} \\
\text { menigkat }(75) & =\frac{75-60}{80-60} \\
& =\frac{75-60}{20} \\
& =\frac{15}{20}=0,75
\end{aligned}
$$

$$
\begin{aligned}
\text { rumus menurun } & =(\mathrm{b}-\mathrm{x}) /(\mathrm{b}-\mathrm{a}) \\
& =\operatorname{Dik}(\mathrm{a}=60)(\mathrm{b}=80)
\end{aligned}
$$

Susi $(\mathrm{x})=75$

Penyelesaian:

$$
\begin{aligned}
\text { menurun }(x) & =\frac{80-x}{80-60} \\
\text { menurun }(75) & =\frac{80-75}{80-60} \\
& =\frac{80-75}{20} \\
& =\frac{5}{20}=0,25
\end{aligned}
$$

Setelah variabel diperoleh nilainya, selanjutnya mencarik nilai z untuk setiap aturan.

R1] IF Kinerja Mengecewakan AND

Kedisiplinan Buruk AND Kemampuan

Menurun THEN Reward Tidak Dapat

$(0.05 ; 0.05 ; 0.25) \min =0.05$

$\mathrm{z} 1=(50-\mathrm{z}) / 10=0.05$

$=50-(0.05 * 10)=\mathbf{4 9}, 5$ (Tidak Dapat)

[R2] IF Kinerja Mengecewakan AND

Kedisiplinan Buruk AND Kemampuan

Meningkat THEN Reward Tidak Dapat

$(0.05 ; 0.05 ; 0.75) \mathrm{min}=0.05$

$\mathrm{z} 2=(50-\mathrm{z}) / 10=0.05$

$=50-(0.05 * 10)=\mathbf{4 9}, 5$ (Tidak Dapat $)$

[R3] IF Kinerja Mengecewakan AND

Kedisiplinan Baik AND Kemampuan

Menurun THEN Reward Tidak Dapat

$(0.05 ; 0,95 ; 0.25) \mathrm{min}=0.05$

$\mathrm{z} 3=(50-\mathrm{z}) / 10=0.05$

$=50-(0.05 * 10)=\mathbf{4 9 , 5}$ (Tidak Dapat)

[R4] IF Kinerja Mengecewakan AND

Kedisiplinan Baik AND Kemampuan

Meningkat THEN Reward

Dipertimbangkan

$(0.05 ; 0,95 ; 0.75) \mathrm{min}=0.05$

$\mathrm{z} 41=(\mathrm{z}-40) / 10=0.05$

$=40+(0.05 * 10)=40,5$

$\mathrm{z} 42=(60-\mathrm{z}) / 10=0,05$

$=60-(0.05 * 10)=59,5$

Maka Nilai

$\mathrm{z} 4=(40,5+59,5) / 2=\mathbf{5 0}$ (Dipertimbangkan)

[R5] IF Kinerja Memuaskan AND Kedisiplinan Buruk AND Kemampuan Menurun THEN Reward Tidak Dapat

$(0.95 ; 0.05 ; 0.25)$ min $=0.05$

$\mathrm{z} 5=(50-\mathrm{z}) / 10=0,05$

$=50-(0.05 * 10)=49.5$ (Tidak Dapat)

[R6] IF Kinerja Memuaskan AND Kedisiplinan

Baik AND Kemampuan Menurun THEN

Reward Dipertimbangkan

$(0.95 ; 0.95 ; 0.25) \mathrm{min}=0.25$

$\mathrm{z} 61=(\mathrm{z}-40) / 10=0.25$

$=40+(0.25 * 10)=42.5$

$\mathrm{z} 62=(60-\mathrm{z}) / 10=0.25$

$=60-(0.25 * 10)=57.5$

Maka Nilai

$\mathrm{z} 6=(42.5+57.5) / 2=\mathbf{5 0}$ (Dipertimbangkan)

[R7] IF Kinerja Memuaskan AND Kedisiplinan Buruk AND Kemampuan Meningkat

THEN Reward Dipertimbangkan

$(0.95 ; 0.05 ; 0.75) \mathrm{min}=0.05$

$\mathrm{z} 71=(\mathrm{z}-40) / 10=0.05$

$=40+(0.05 * 10)=40.5$

$\mathrm{z} 72=(60-\mathrm{z}) / 10=0.05$

$=60-(0.05 * 10)=59.5$

Maka Nilai

$\mathrm{z} 7=(40.5+59,5) / 2=\mathbf{5 0}$ (Dipertimbangkan)

[R8] IF Kinerja Memuaskan AND Kedisiplinan

Baik AND Kemampuan Meningkat

THEN Reward Dapat

$(0.95 ; 0,95 ; 0.75) \mathrm{min}=0.75$

$\mathrm{z} 8=(\mathrm{z}-60) / 10=0.75$

$=60+(0.75 * 10)=67.5$ (Dapat)

$\mathrm{Z}$

$=\underline{(0.05 * 49.5)+(0.05 * 49.5)+(0.05 * 49.5)+(}$ $0.05 * 50)+(0.05 * 49.5)+(0.25 * 50)+(0.05 * 5$ $\underline{0)+(0.75 * 67.5)}$ 
I N F ORM A T I R

Jurnal Informatika, Manajemen dan Komputer, Vol. 10 No. 2, Desember 2017

eISSN : 2580-3042

pISSN : 1979-0694

$0.05+0.05+0.05+0.05+0.05+0.25+0.05+0$ 75

$\mathrm{Z}=\underline{78.025}$

1.3

$Z=\underline{60.0192307692}$

Hasil = dipertimbangkan Mendapatkan Reward Rp. 50,000

ANSOR dan SUSI dengan REWARD yang didapti sebesar Rp 100.000.

c. Context Diagram

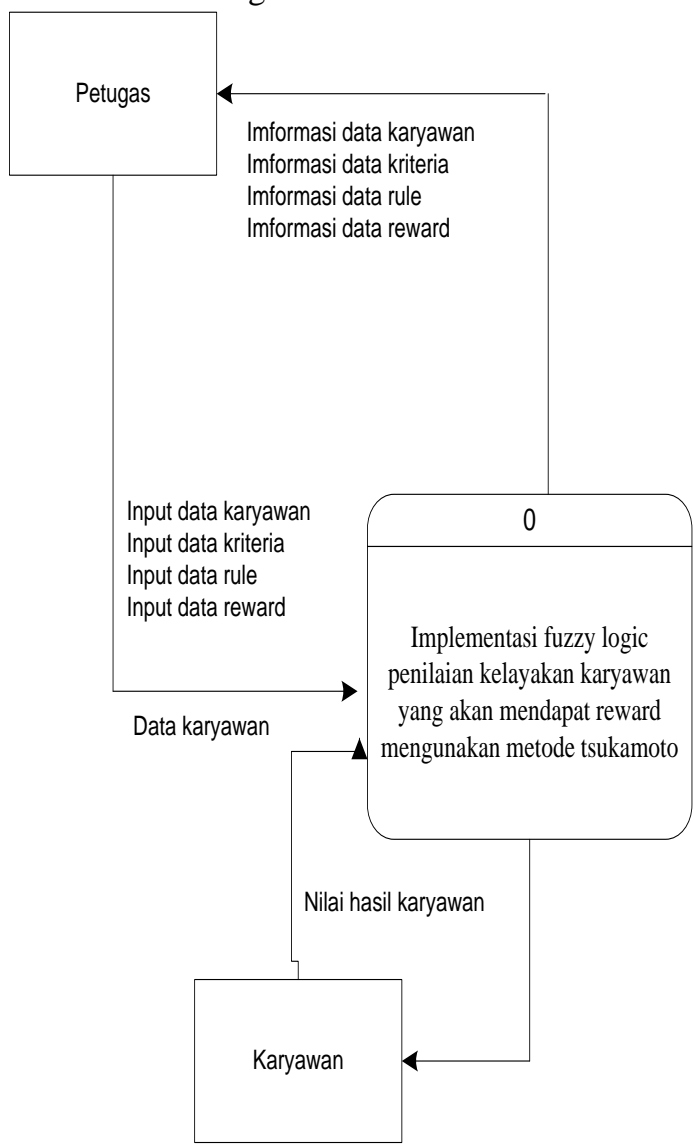

Gambar 12. Context Diagram

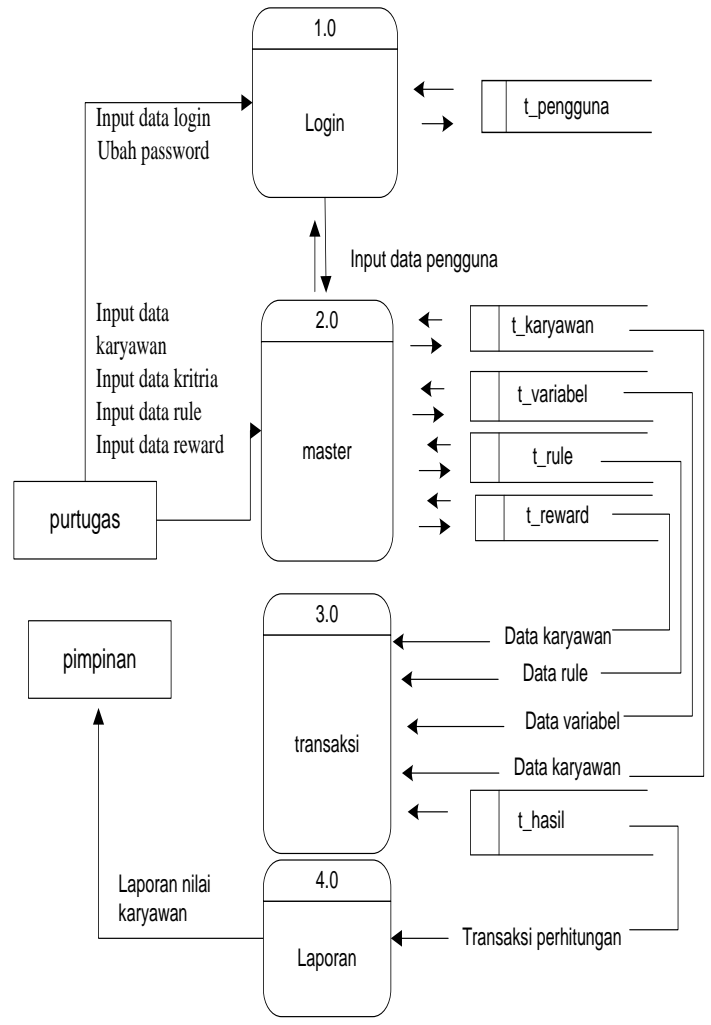

Gambar 13. Flow Diagram

e. Entity Relationship Diagram

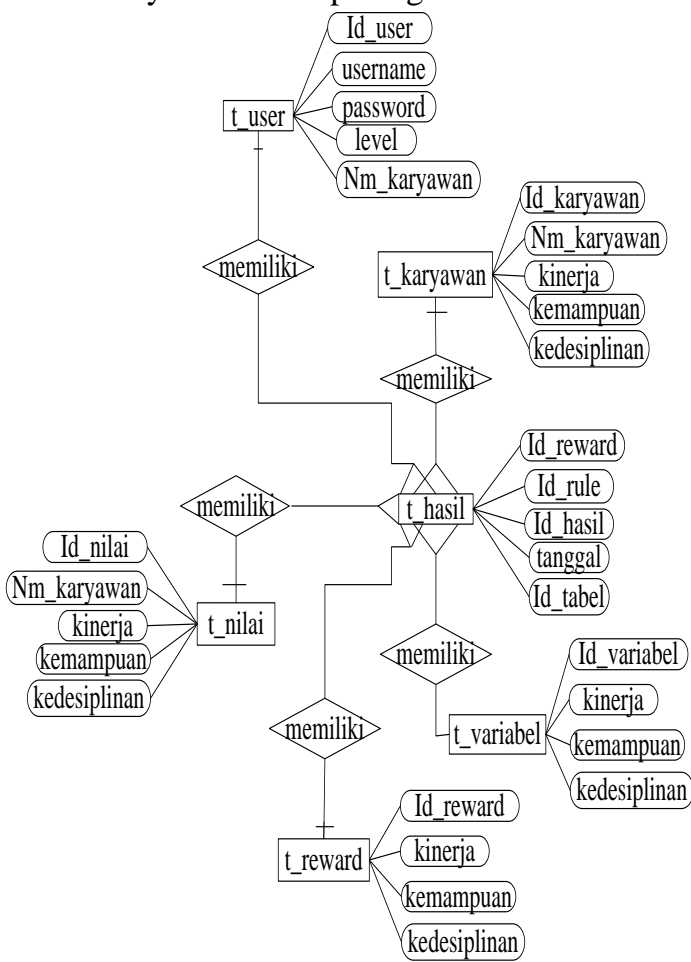

Gambar 14. Entity Relationship Diagram

d. Data Flow Diagram

\section{f. Pembahan sistem}


I N F ORM A T I R

Jurnal Informatika, Manajemen dan Komputer, Vol. 10 No. 2, Desember 2017

eISSN : 2580-3042

pISSN : 1979-0694

1. Halaman Login

Setelah masuk kedalam sistem, user harus terlebih dahulu login dengan cara menginput user dan password dengan benar

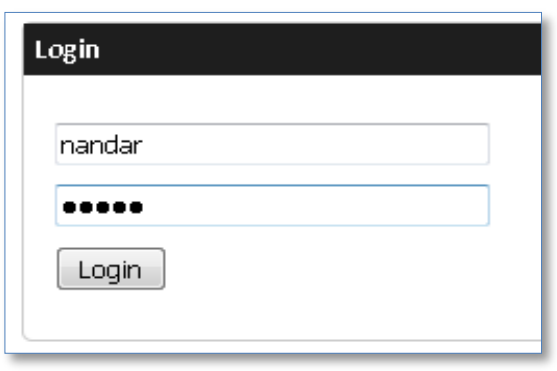

Gambar 15. Login Aplikasi

2. Halaman Utama

Pada from menu utama terdapat menu yang memiliki beberapa sub-sub menu yaitu:

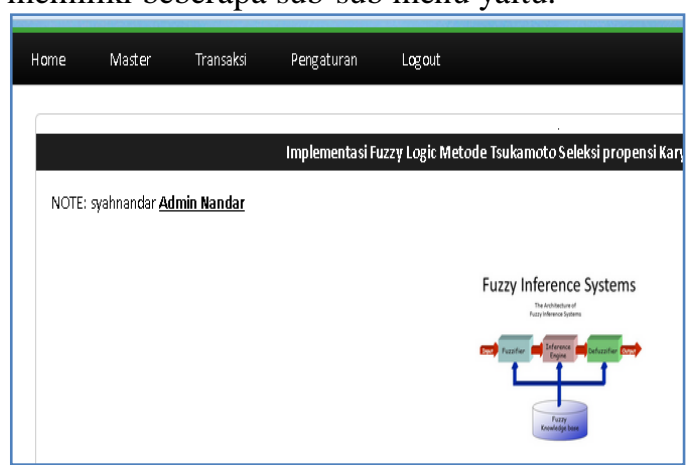

Gambar 16. from menu utama

\section{Halaman Input Data User}

Pada from input data user digunakan untuk melakuakan pengantian password sebagai penggunaan baru.

\begin{tabular}{|c|c|c|}
\hline \multicolumn{3}{|c|}{ Master Data User - Ubah } \\
\hline Nama Lengkap & \multicolumn{2}{|c|}{ Admin Nandar } \\
\hline Username & \multicolumn{2}{|l|}{123} \\
\hline \multirow[t]{2}{*}{ Password } & \multicolumn{2}{|c|}{$\begin{array}{l}123 \\
\text { *Kosongkan Password Jika Tidak Di Ubah }\end{array}$} \\
\hline & Ubah & Kembali \\
\hline
\end{tabular}

Gambar 17. From input data user

\section{Halaman Input Data nilai}

Pada from input data nilai karyawan adalah berisis nilai yang didapati karyawan diperusahaan roti tersebut.

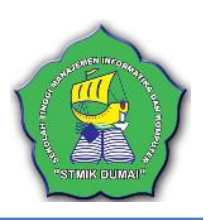

Master Data Karyauan - Ubah
\begin{tabular}{|l|l|l|}
\hline Nama Karyawan & $:$ & ANSOR \\
\hline Tempat Lahir & $:$ & DUMAI \\
\hline Tanggal Lahir & $:$ & $1993-09-01$ \\
\hline Jenis Kelamin & $:$ & O Laki-Laki P Perempuan \\
\hline No HP & $:$ & 085273336333 \\
\hline Agama & $:$ & Islam \\
\hline & & Ubah Kembali \\
\hline
\end{tabular}

Gambar 18. from input data nilai

6. Halaman Output Transaksi

Pada from transaksi berisi proses dari penjumlahan seluruh nilai, untuk mendapatkan keputusan karyawan yang layak mendapat reward atas prestasinya

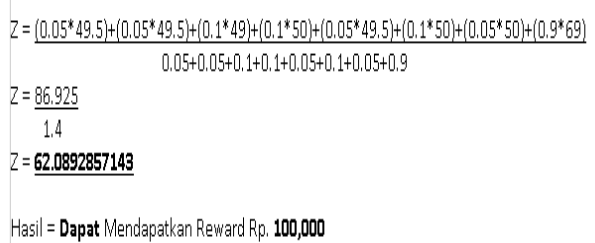

Gambar 19. Proses output

7. Laporan Data Penilaian Karyawan

Pada halaman laporan adalah hasil input dari tabel yang telah ditentukan dengan nilainya

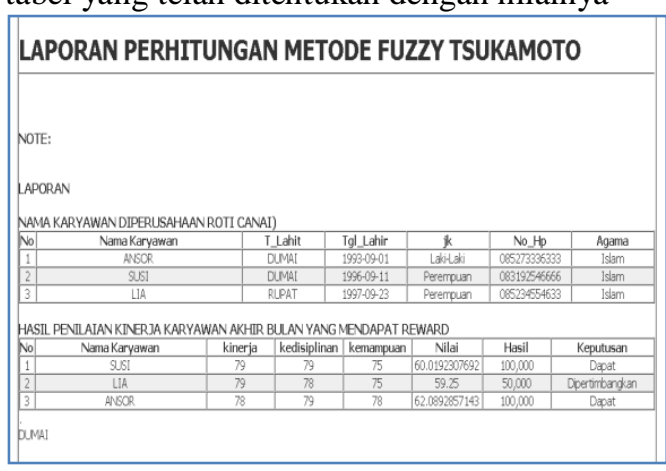

Gambar 20. Laporan

\section{KESIMPULAN}

Bedasarkan penelitian yang telah dilakukan ditoko pembuatan roti dan ditemui beberapa permasalahan yang dihadapi, Maka dapat disimpulkan bahawa rasanya perlu untuk diterapkan sistem komputer dengan mengunakan sebuah aplikasi. Yang mana nantinya dapat mengantikan sistem lama yang ditangani secara manual dan menjadi sistem baru. dapat diambil beberapa kesimpulan:

1. Dengan mengunakan sistem ini maka dapat mempermudahkan dalam penilaian kinerja 
IN F ORM A T IK A

Jurnal Informatika, Manajemen dan Komputer, Vol. 10 No. 2, Desember 2017

eISSN : 2580-3042

pISSN : 1979-0694

dan sesuai dengan kualitas mereka miliki, baik perusahan kecil atau perusahan besar.

2. Sistem komputerisasi dengan pemrograman php ini adalah salah satu sistem proses penilaian kinerja karyawan yang diterapkan berdasarkan dari metode fazzy logic.

\section{REFERENSI}

Dharmawati, A., \& Aprilianto, H. (2014). Penerapan Metode Fuzzy Tsukamoto Untuk Prediksi Nilai Tukar Rupiah. Jutisi, 3(3), 609-616. Retrieved From Http://Ojs.Stmik-

Banjarbaru.Ac.Id/Index.Php/Jutisi/Article/ View/18

Ekajaya, F., Hidayat, N., \& Ananta, M. T. (2018). Diagnosis Penyakit Tht Menggunakan Metode Fuzzy Tsukamoto Berbasis Android. Jurnal Pengembangan Teknologi Informasi Dan Ilmu Komputer, 2(8), 2361-2365. Retrieved From Http://Ojs.Uho.Ac.Id/Index.Php/Semantik/ Article/View/414

Elisawati. (2017). Sistem Deteksi Objek Dengan Menggunakan Sensor Ultrasonik Berbasis Fuzzy. Jurnal Informatika, Manajemen Dan Komputer, 9(1), 10-14. Retrieved From

Http://Ejournal.Stmikdumai.Ac.Id/Index.Ph $\mathrm{p} /$ Path/Article/View/58

Fristanto, H. T. (2013). Rancang Bangun Sistem Informasi Pembayaran Sumbangan Pembinaan Pendidikan (Spp) Dan Insidental Pada Sekolah Menengah Kejuruan Muhammadiyah Tinatar Punung Hendria Tony Fristanto 1) Bambang Eka Purnama 2) Sukadi 3). Indonesian Journal On Networking And Security, 3(4), 1-5. Retrieved From Http://Ijns.Org/Journal/Index.Php/Ijns/Arti cle/View/192

Hasanh, S. N., \& Widiastuti, N. I. (2014). Representasi Emosi Menggunakan Logika Fuzzy Pada Permainan Bonny' S Tooth Booth Jurnal Ilmiah Komputer Dan Informatika ( Komputa ). Ilmiah Komputer Dan Informatika (Komputa), 3(2). Retrieved From Http://Pilar.Nusamandiri.Ac.Id/Index.Php/ Pilar/Article/View/58

Iswandy, E. (2015). Sistem Penunjang Keputusan Untuk Menentukan Penerimaan Dana 